Ketoprofen Plaster(Kefen $\left.{ }^{\circledR}\right)$ 의 약동학적 특성 및

$$
\text { 피부자극성 평가* }
$$

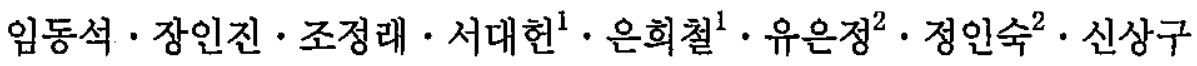

$=$ Abstract $=$

Evaluation of Pharmacokinetics and Skin Irritation of Transdermal Ketoprofen Plaster $\left(\operatorname{Kefen}^{8}\right)$ in Healthy Volunteers

Dong-Seok Yim, In-Jin Jang, Jeong-Rae Cho, Dae-Heon Suh', Hee-Chul Eun', Eun-Chung $\mathrm{Yu}^{2}$, In-Sook Jeong ${ }^{2}$, Sang-Goo Shin

Department of Pharmacology, Clinical Pharmacology Unit/SNUH and 'Department of Dermatology, Seoul National University, College of Medicine, ${ }^{2}$ Clinical Research Center/SNUH, Seoul, Korea

Background : Ketoprofen, a nonsteroidal antiinflammatory drug, requires frequent oral dosing due to its short half-life and quite often results in gastrointestinal adverse effects by oral route. A transdermal delivery system of ketoprofen(Kefen ${ }^{(2)}$ plaster), which would have less such shortcomings, was developed and evaluated of the pharmaco- kinetic characteristics and safety i.e., local skin irritation.

Method : Fifteen healthy volunteers were recruited for the study. Blood samples were drawn 10 times during 24 hour application period and 5 times after detaching the plaster. Plasma ketoprofen concentration was measured by high performance liquid chromatography method. Extent of delivery was measured by residual test and kinetics were analysed by compartment and non-compartment models. Skin irritaition was evaluated by transepidermal water loss and superficial blood flow changes measured by laser doppler flowmeter before application, 1 and 6 hours after detachment of plaster. Skin irritaion of the plaster was compared to surgical plaster.

* 본 연구는 1996년도 서울대학교병원 위탁연구비 보조에 의해 이루어졌음.

서울대학교 의과대학 약리학교실 및 서울대학교병원 임상약리학 Unit

서울대학교병원 피부과

서울대학교병원 Clinical Research Center ${ }^{2}$

교신저자 : 신상구, 서울특별시 종로구 연건동 28, 110-799 
- D. S. Yim, et al : Pharmacokinetics of Ketoprofen Plaster -

Results : Amount of ketoprofen delivered was $11.21 \pm 3.09 \mathrm{mg}$ (mean \pm S.D.) per plaster, which was $37.4 \%$ of $30 \mathrm{mg}$ dose. Plasma ketoprofen concentration reached peak at 6 to 14 hours after application with mean peak concentration of $164.6 \mathrm{ng} / \mathrm{ml}$. Volume of distribution was $0.44 \pm 0.26 \mathrm{~L} / \mathrm{kg}$ and half-life was $2.44 \pm 0.48$ hours in average. Initial fast dose of $3.95 \pm 1.84 \mathrm{mg}$ was delivered by 9.9 hours in average. Total area under the plasma concentration time curve was $3.17 \pm 1.55 \mu \mathrm{g} / \mathrm{hr} \cdot \mathrm{ml}$ and mean plasma clearance was $0.06 \pm 0.02 \mathrm{~L} / \mathrm{hr} / \mathrm{kg}$. From the kinetic parameters, it was simulated that application of the plaster every 12 hours would attain average ketoprofen concentration of $171 \mathrm{ng} / \mathrm{ml}$. Kefen ${ }^{\circledR}$ plaster showed no significant skin irritation after $24 \mathrm{hr}$ application.

Conclusion : The result of kinetic analysis showed ketoprofen plaster, Kefen ${ }^{(B)}$, delivered significant amount of ketoprofen up to 24 hour application period. The plaster was expected to have significant local clinical effect in view of its pharmacokinetic characteristics and lack of skin irritation.

KEY WORDS : Ketoprofen - Transdermal delivery · Pharmacokinetics · Skin irritaion.

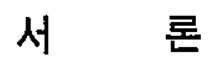

비스테로이드계 소염, 진통제인 ketoprofen은 경구복용시 위장관장애가 혼히 문제되며 짧은 반감기로 인해 1일 3 내지 4화 투여가 필요하 다. 최근 경구로 복용하였을 때 위장관 부작용 이 있는 약물, 위장관에서 홉수되기 어려운 약 물, 위장관에서 분해되는 약물 및 간대사를 받 는 약물 등을 피부를 통하여 체내에 전달하는 제형인 경피홉수제제(Transdermal Delivery System)의 연구개발이 활발하다. 톡히 소염진통 경 피흡제제의 개발은 종래 상용되어 왔던 살리시 산 유도체를 주성분으로 하는 파스류나 습포제 보다는 경구투여 등에서 우수한 약효가 입중된 소염진통제를 이용하여 필요로 하는 조직에만 약물을 전달하여 치료효과를 극대화하는 소염진 통 plaster제의 개발이 두드러져 있다. 따라서 ketoprofen의 경우 경피흡수제를 개발하여 국소 이환 부위에 적용하면 근육, 관절 등의 국소조 직에 높은 농도로 작용하여 전신순환이나 위장 관내 필요 이상의 고농도 도달을 방지하여 위장 장애, 신장애, 등의 부작용을 줄일 수 있을 것이 다. 또한 경구투여와 달리 흡수가 지속적으로 일어나게 함으로써 약물의 투여 횟수를 줄일 수 있으며 국소 약물농도의 fluctuation을 줄여 지 속적인 효과를 기대할 수 있다.

최근 ketoprofen의 국부적 적용제제가 독일 ${ }^{1}$, 일본 ${ }^{23)}$, 및 국내 ${ }^{4)}$ 에서 개발되어 시판되고 있으 며 일본에서 개발된 첩포체형은 시간당 $2 \sim 4 \mu \mathrm{g}$ $/ \mathrm{cm}^{3}$ 의 피부투과성을 보여 12 시간 간격으로 사 용토록 되어 있다. 본 연구에서 검토하는 제형 은 일본의 첩포제형 보다 약 5 배의 in vitro 피 부투과성을 보인다 ${ }^{23)}$. 이에 본 연구에서는 피부 투과성을 증가시킨 ketoprofen plaster(상품명 : $\mathrm{Kefen}^{(B)}$ )에 대한 인체 약동학적 특성과 안전성을 
검토하였다.

\section{대상 및 방법}

\section{1. 피험자 및 시힘방법}

15 명의 건강한 남성 지원자가 임상시험에 참 가하였으며 연령은 22세에서 33세 사이였고 체 중이 이상체중(ideal body weight)의 $10 \%$ 내외 인 사람으로 하였다(Table 1). 피험자는 시험전 본 시험과 이에 수반될 수 있는 부작용에 대해 충분히 설명을 듣고 동의서에 자의로 서명한 자 를 대상으로 하였다. 연구개시전에 혈액화학, 심 전도 및 노검사를 통해 간장, 심장 및 신기능에 이상이 없는 지원자만을 대상으로 하였다. 이외 plaster 부착 부위에 과다한 체모가 있는 자, 펴

Table 1. Demograpic data of 15 subjects.

\begin{tabular}{cccc}
\hline ID & 체중 $(\mathrm{kg})$ & 키 $(\mathrm{cm})$ & 나이(세) \\
\hline \hline KT-1 & 70.0 & 170 & 23 \\
KT-2 & 65.0 & 170 & 25 \\
KT-3 & 67.0 & 170 & 24 \\
KT-4 & 60.0 & 170 & 23 \\
KT-5 & 74.0 & 174 & 33 \\
KT-6 & 59.5 & 168 & 24 \\
KT-7 & 62.0 & 165 & 22 \\
KT-8 & 73.0 & 178 & 24 \\
KT-9 & 57.5 & 167 & 22 \\
KT-10 & 79.5 & 180 & 23 \\
KT-11 & 65.0 & 172 & 23 \\
KT-12 & 63.0 & 168 & 24 \\
KT-13 & 61.5 & 176 & 25 \\
KT-14 & 78.5 & 178 & 24 \\
KT-15 & 59.5 & 165 & 25 \\
\hline 평 균 & 66.3 & 171.4 & 24.3 \\
SD & 7.1 & 4.8 & 2.6 \\
\hline
\end{tabular}

부질환자, ketoprofen이나 타 NSAIDs 또는 plaster에 과민반응의 경력이 있는 자, 연구개시 2 일 전에 다른 약물을 복용한 자 등은 제외하였다.

피험자는 시험달일 가벼운 아침 식사를 허용 하였으며 상배부에 2매의 plaster를 부착하였다. 부착 plaster는 피부밀착을 위해 피부자극이 적 은 surgical tape로 고정하였다.

피험자는 plaster부착 1시간 전부터 부착한 24 시간 동안 및 plaster를 제거 후 6시간 동안 목 욕이나 부착부워의 세척을 금지하도록 하였다. 24시간 부착후 제거된 plaster는 $50 \mathrm{ml}$ culture tube에 밀봉하여 보관한 후, 잔여 ketoprofen 촉 정 때까지 $-70^{\circ} \mathrm{C}$ 에 보관하였다.

Plaster 부착 전 상박 전완부의 정맥내 카테터 를 통해 대조혈액 $10 \mathrm{mI}$ 를 채혈한 후 PRN adaptor(Deseret $\left.{ }^{(B)}\right)$ 를 설치하고 heparin $(50 \mathrm{U} / \mathrm{ml})$ 으로 locking하였다. Plaster 부착 후 $0.5,1,2$, $3,4,6,9,12,14,24$ 시간에 $7 \mathrm{ml}$ 의 혈액을 채 혈하였고, 24시간 후 plaster를 제거하고 plaster 제거 후 $0.5,1,2,4,6$ 시간 후 채혈하였다. 채혈 액은 $100 \mathrm{~g}, 10$ 분간 원심분리하여 혈장은 약물 농도 측정시까지 $-70^{\circ} \mathrm{C}$ 에서 보관하였다.

피부의 주관적, 객관적 소견을 plaster 부착 전 1시간과 plaster 제거 후 1시간, 6시간 후에 관찰하였다. 피부의 주관적 자극 평가는 modified Draize scale을 이용하여 평가하였다. 피부 자극의 객관적 평가로써 evaporimetry에 의해 피부 수분손실을 부착전과 제거 후 1시간, 6시 간에 측정하였으며 또한 laser doppler를 이용 하여 위와 동일시간에 표퍼 혈류량을 측정함으 로써 피부자극의 지표로 검토하었다.

\section{2. 혈장 Ketoprofen의 정량}

혈장중 ketoprofen 분석은 Royer 등의 방법 ()을 일부 수정한 고성능액체크로마토그래피(HPLC) 
- D. S. Yim, et al : Pharmacokinetics of Ketoprofen Plaster -

법에 준하였으며, 이 때 내부표준물질로는 indobufen을 사용하였다. 시료혈장 $1 \mathrm{ml}$ 를 원심분 리용 시험관에 넣고 $1 \mathrm{M} \mathrm{H}_{3} \mathrm{PO}_{4} 1 \mathrm{ml}$ 를 넣어 산 성화시킨 후 내부표준액 $100 \mu \mathrm{l}$ 를 가하여 HPLC 로 분석하였다.

시험에 사용한 plaster 중의 ketoprofen 양은 다음과 같은 추출과정을 5회 반복하여 그 평균 으로 하였다. 시험에 사용한 동일 lot의 plaster 2매를 잘게 잘라 삼각플라스크에 넣고, $\mathrm{CHCl}_{3}$ $50 \mathrm{ml}$ 를 가하여 초음파추출기에 넣고, 20 분간 초음파추출하여, 추출액을 $200 \mathrm{ml}$ 용량플라스크 로 수거하였다. 이 추출과정을 3회 반복하여 추 출액을 합치고, 여기에 내부표준액 $5 \mathrm{ml}$ 를 가하 여 최종부피가 $200 \mathrm{ml}$ 가 되게 하였다. 피험자에! 게서 제거한 시험용 plaster 중의 ketoprofen 양 도 위와 같은 추출방법으로 추출하여 혈장중 ketoprofen 분석법과 동일한 방법으로 분석하였 다. HPLC 분석에 이용된 기기는 Hitachi P-6000 Pump, Hitachi D-4200 UV/Visible Detector, Gilson 232-Bio Sample Autoinjector, Hitachi D-2500 Chromato-Integrater를 이용하였다. 칼럼은 Cosmosil $5 \mathrm{Cl} 18 \mathrm{AR}(\varnothing 4.6 \times 150 \mathrm{~mm}, 5 \mu$ m particle size, Nacalai Tesque, Japan)를 이용 하였고 이동상은 $0.01 \mathrm{M}$ phosphate buffer $(\mathrm{pH}$ 7.4) $:$ Acetonitrile $=84: 16(\mathrm{v} / \mathrm{v})$ 을 $0.7 \mathrm{ml} / \mathrm{min}$ 의 유속으로 흘렸으며 검출은 $258 \mathrm{~nm}$ 의 파장에 서 시행하였다. 이상의 조건에서 혈장 ketoprofen의 검출한계는 $5 \mathrm{ng} / \mathrm{ml}$ 이었다. 내부표준물질 에 대한 peak height 비로부터 얻은 표준겸량선 을 이용하여 경시적인 ketoprofen 혈장중 농도 를 산출하였으며 $50 \mathrm{ng} / \mathrm{ml}$ 과 $150 \mathrm{ng} / \mathrm{ml}$ 농도의 표준시료에서 변이계수(coefficient of variation) 는 $6 \%$ 와 $5 \%$ 이었다.

Ketoprofen 혈장농도의 변화는 non-compartment model을 이용하여 농도곡선하면적(AUC)
을 산출하였고 plaster내 잔류량으로부터 산출한 홉수용량을 이용하여 ketoprofen plaster의 피부 penetration 양상을 2-component simultaneous infusion model을. 적용하여 PCNONLIN에 의해 검토하였닥.

$\mathrm{dCp} / \mathrm{dt}=\left(\mathrm{DB} / \mathrm{tB}+\mathrm{DM} / \mathrm{ti}-\mathrm{CL}^{*} \mathrm{Cp}\right) / \mathrm{Vd}$

$\mathrm{Cp}$ : 혈장약물농도

$\mathrm{DB}$ : 초기 빠른 홉수 용량

$\mathrm{tB}$ : 초기 빠른 홉수 기간

DM : 유지. 홉수 용량

ti : 유지 홉수 기간

$\mathrm{CL}$ : 청소율

$\mathrm{Vd}$ : 분포용적

이러한 분석으로 초기의 빠른 홉수기간, 청소 율, 분포용적, plaster 제거 후 피부내 존재 약물 의 홉수기간, 평균항정상태 혈장농도 등을 산출 하였다.

시험 plaster와 surgical plaster 사이의 피부자 극성의 검토는 피험자에서의 부작용 발생 빈도 및 Draize scale의 score를 비교하였고 경피수분 소실과 표재성혈류의 변화를 paired t-test를 이 용하여 분석 비교하였다.

\section{결 과}

\section{Ketoprofen의 흡수 및 약동화}

Kefen $^{\circledR}$ plaster 24시간 부착 후 ketoprofen의 잔류량 분석결과 plaster 1 매당 평균 흡수량은 $11.21 \pm 3.09 \mathrm{mg}$ 으로 약 $37.4 \%$ 의 홉수율을 보였 다. Plaster로부터 홉수된 ketoprofen의 혈장농도 변화(Figure 1)는 1매의 plaster 부착 후 24시간 까지 평균 혈장농도가 약 $120 \mathrm{ng} / \mathrm{ml}$ 이상으로 유지되는 양상을 보였고 그 때의 평균 총농도곡 선하 면적은 $3.17 \pm 1.55 \mu \mathrm{g} / \mathrm{hr} \cdot \mathrm{ml}$ 였으며 6시 간에서 14 시간 사이예 도달한 평균 최고 혈장농 


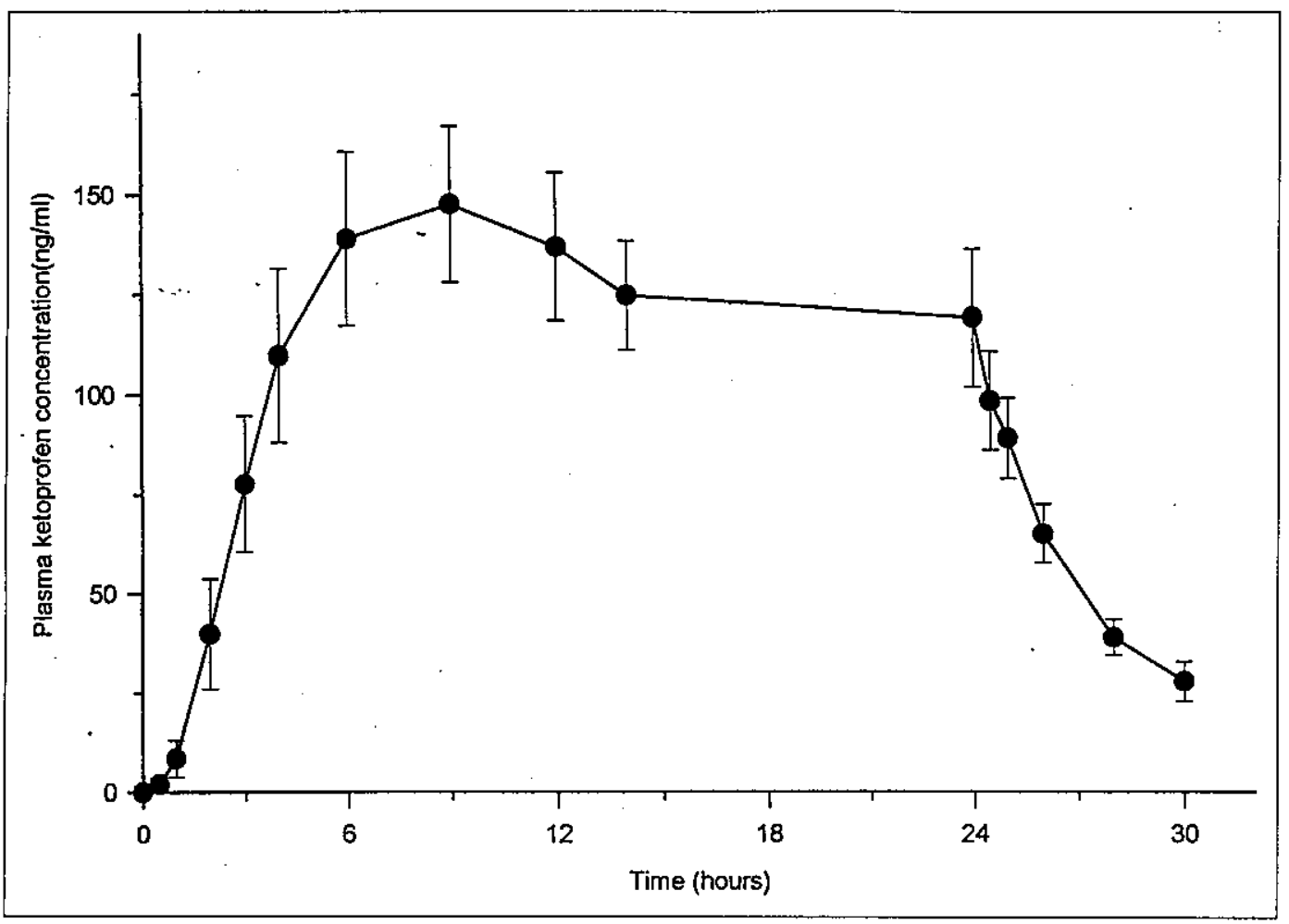

Fig. 1. Average plasma concentration of ketoprofen after application of a Kefen ${ }^{\mathbb{B}}$ plaster in 15 subjects (mean \pm S.E.).

도(Cmax)는 $164.6 \pm 82.0 \mathrm{ng} / \mathrm{ml}$ 이었다. 이러한 약물농도 데이터의 1-compartment, 2-infusion 모델에 따른 분석결과 분포용적은 $0.44 \pm 0.26$ $\mathrm{L} / \mathrm{kg}$ 이였으며 초기의 빠른 홉수기간(tB)은 평균 $9.7 \pm 1.9$ 시간이었고 느린 홉수속도로 24 시간 동 안 홉수된 양(DM)은 $8.20 \pm 2.86 \mathrm{mg}$ 으로 전체 흡수량의 $74 \%$ 였다(Table 2).

15 명의 피험자에서 관찰된 평균 혈장농도와 약동학 파라메터의 평균값을 이용하여 모델에 적용하여 예측한 농도(Figure 2) 비교시 이러한 모델에 따른 분석이 혈장농도 변화를 비교적 잘 반염함을 알 수 있었다.

\section{2. 피부자극성 검토}

대조 제제로 이용한 surgical plaster와 $\operatorname{Kefen}^{(}$ plaster에서 24시간 피부부착 후 Draize sclae에 의해 피부자극성을 검토하였다. 그 결과 plaster 를 제거한 다음 1 시간 및 6시간 경과후의 부착 부위에서 유의한 발적이나 부종은 관찰되지 않 았다.

경피수분소실은 surgical plaster가 부착 전 $6.40 \pm 6.86 \mathrm{~g} / \mathrm{m}^{2} \cdot \mathrm{hr}$ 에서 24시간 부착 후 제거 1시간에 $4.78 \pm 2.61$, 6시간에 $4.27 \pm 2.52 \mathrm{~g} / \mathrm{m}^{2}$ - $\mathrm{hr}$ 로 오히려 감소하였으며 2장의 plaster 적용 의 경우 부착 전 부착부위에서 $7.07 \pm 8.71$ 과 24 시간 부착 후 제거 1 시간에 $5.53 \pm 3.60$ 과 6시간 에 $4.73 \pm 3.26 \mathrm{~g} / \mathrm{m}^{2} \cdot \mathrm{hr}$ 로 surgical plaster와 유 사한 변화를 보였으며 그 값의 범위 또한 1에서 $7 \mathrm{~g} / \mathrm{m}^{2} \cdot \mathrm{hr}$ 로 임상적으로 유의한 값이 아니었으 며 대조로 사용한 surgical plaster와 비교시 통계 
- D. S. Yim, et al : Pharmacokinetics of Ketoprofen Plaster -

Table 2. Pharmacokinetic parameters of $\operatorname{Kefen}^{B}$ plaster

\begin{tabular}{ccccccccccc}
\hline ID & $\begin{array}{c}\text { Dose } \\
(\mathrm{mg})\end{array}$ & $\begin{array}{c}\text { Cmax } \\
(\mathrm{ng} / \mathrm{ml})\end{array}$ & $\begin{array}{c}\mathrm{Tmax} \\
(\mathrm{hr})\end{array}$ & $\begin{array}{c}\mathrm{T} 1 / 2 \\
(\mathrm{hr})\end{array}$ & $\begin{array}{c}\text { AUC } \infty \\
(\mathrm{ng} / \mathrm{ml} \cdot \mathrm{hr})\end{array}$ & $\begin{array}{c}\mathrm{Vd} \\
(\mathrm{L} / \mathrm{kg})\end{array}$ & $\begin{array}{c}\mathrm{CL} \\
(\mathrm{L} / \mathrm{kg} / \mathrm{hr})\end{array}$ & $\begin{array}{c}\text { Tfst } \\
(\mathrm{hr})\end{array}$ & $\begin{array}{c}\text { Tinf } \\
(\mathrm{hr})\end{array}$ & $\begin{array}{c}\text { FRC } \\
(\%)\end{array}$ \\
\hline KT-1 & 11.64 & 109.3 & 6.00 & 2.1 & 1925.9 & 0.38 & 0.09 & 9.98 & 23.95 & 73.3 \\
KT-2 & 8.99 & 71.4 & 14.00 & 2.8 & 1472.7 & 0.78 & 0.09 & 9.36 & 24.34 & 77.2 \\
KT-3 & 12.94 & 107.9 & 12.00 & 3.5 & 2344.7 & 0.56 & 0.07 & 11.01 & 22.15 & 84.1 \\
KT-4 & 8.70 & 80.3 & 12.00 & 3.2 & 1612.9 & 0.96 & 0.08 & 11.56 & 22.35 & 69.9 \\
KT-5 & 11.60 & 107.1 & 6.00 & 2.5 & 2195.1 & 0.36 & 0.07 & 8.23 & 24.18 & 77.2 \\
KT-6 & 10.84 & 232.9 & 12.00 & 2.8 & 3775.7 & 0.22 & 0.05 & 11.99 & 23.89 & 41.4 \\
KT-7 & 15.46 & 342.2 & 6.00 & 2.1 & 6813.7 & 0.13 & 0.04 & 8.54 & 24.00 & 71.1 \\
KT-8 & 11.85 & 84.8 & 9.00 & 2.2 & 1822.8 & 0.71 & 0.08 & 8.88 & 24.00 & 68.7 \\
KT-9 & 8.43 & 161.8 & 12.00 & 2.6 & 3388.8 & 0.30 & 0.04 & 12.49 & 23.99 & 78.1 \\
KT-10 & 3.70 & 148.9 & 14.00 & 2.5 & 3125.8 & 0.08 & 0.01 & 11.26 & 22.02 & 92.9 \\
KT-11 & 16.79 & 253.2 & 4.00 & 2.0 & 5073.9 & 0.21 & 0.05 & 6.11 & 24.00 & 84.0 \\
KT-12 & 10.16 & 94.8 & 9.00 & 2.2 & 1744.8 & 0.64 & 0.08 & 10.99 & 23.99 & 94.3 \\
KT-13 & 12.51 & 185.7 & 9.00 & 1.9 & 3837.7 & 0.62 & 0.04 & 9.00 & 20.92 & 70.0 \\
KT-14 & 12.02 & 253.5 & 6.00 & 2.0 & 3513.9 & 0.43 & 0.04 & 6.72 & 23.98 & 41.0 \\
KT-15 & 12.53 & 234.9 & 9.00 & 2.1 & 4961.2 & 0.26 & 0.04 & 11.75 & 23.30 & 84.5 \\
\hline Mean & 11.21 & 164.6 & 9.33 & 2.4 & 3174.0 & 0.44 & 0.06 & 9.86 & 23.40 & 74.0 \\
S.D. & 3.09 & 82.0 & 3.22 & 0.5 & 1545.1 & 0.26 & 0.02 & 1.94 & 1.03 & 15.5 \\
\hline
\end{tabular}

Tfst : duration of fast input

Tinf : duration of slower maintenance input

FRC : percent of dose delivered by slow maintenance input

적으로 유의한 차이를 보이지 않았다. Laser

doppler flowmetry로 본 포재성 혈류변화의 경 우 surgical plaster가 $5.20 \pm 1.78$ 에서 제거 후 1 시간에 $6.93 \pm 2.15,6$ 시간에 $6.67 \pm 2.72$ Volt로 증가하였고 plaster의 경우 부착 전 $4.20 \pm 1.86$, plaster 제거 1 시간 후 $6.53 \pm 2.26,6$ 시간에 6.20 \pm 2.88 volt로 증가하였으나 통계적으로나 임상 적으로 유의한 차이는 아니었다(Table 3, Figure $3,4)$. 그 외 ketoprofen plaster 부착과 연관된 주관적 증상의 호소나 객관적인 증후는 시험기 간에 걸쳐 관찰되지 않았다.
Ketoprofen plaster체제의 부착에 따른 혈장 ketoprofen의 약동학적 특성은 경구투여시의 보 고들과 비교시 분포용적이 $0.44 \pm 0.26 \mathrm{~L} / \mathrm{kg}$ 으로 경구투여시 $(8 \mathrm{~L})$ 나 정맥투여시의 보고인 0.15 $\mathrm{L} / \mathrm{kg}$ 보다 다소 컸으나 반감기는 $2.44 \pm 0.48$ 시 간으로 경구투여시의 1.1 - 4시간과 비교시 유사 한 값을 보였다. ${ }^{899}$ 분포 용적이 다소 크게 산출 된 것은 본 연구의 약동학 분석 모델에서 산출 된 분포용적은 $\mathrm{Vdss}$ 임에 비해 보고된 값들은 


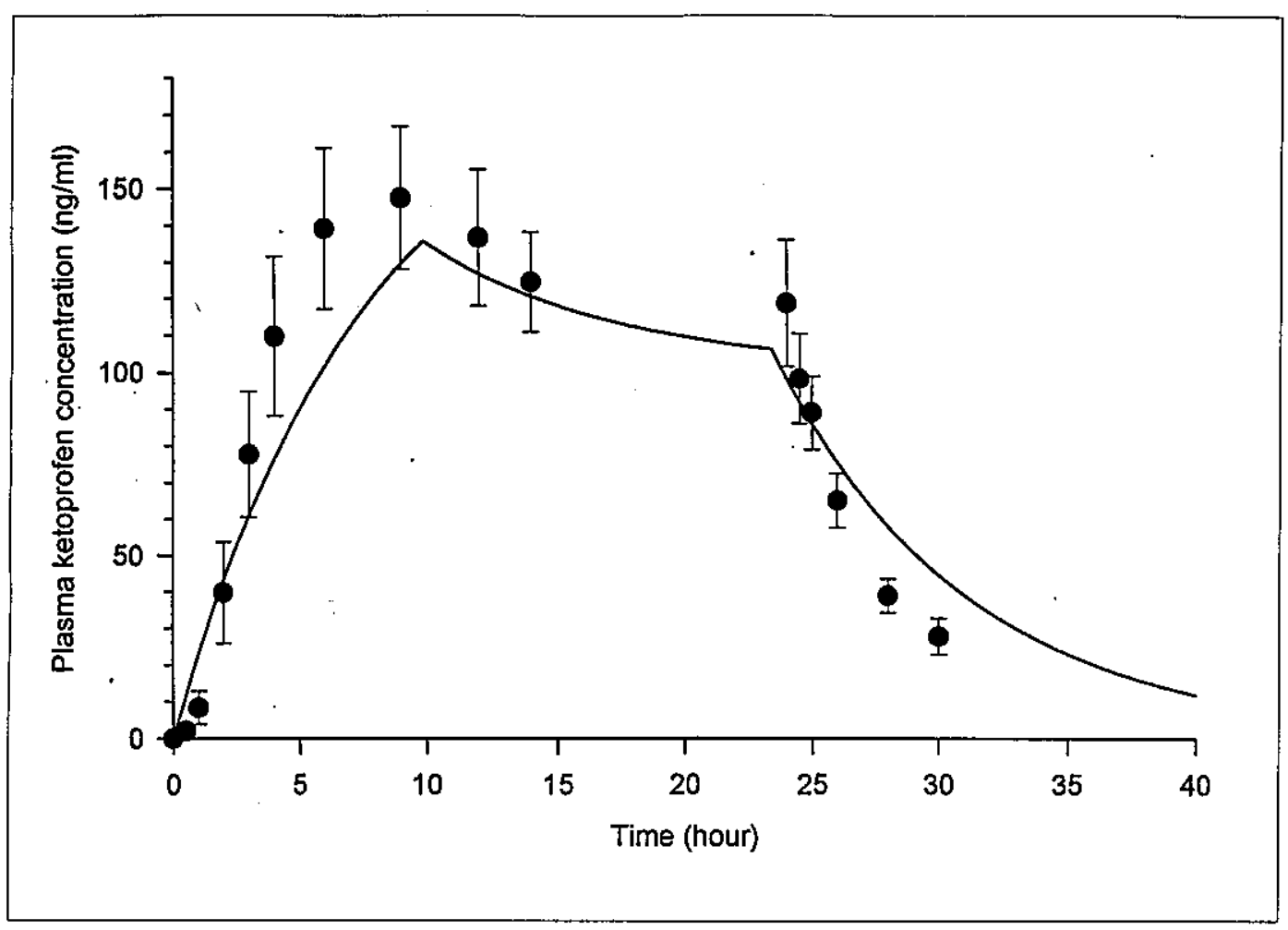

Fig. 2. Simulated(line) and observed(circle) plasma concentration of 15 subjects after application of a Kefen ${ }^{\mathbb{B}}$ plaster.

Table 3. Results of transepidermal water loss and laser doppler flowmetry in 15 subjects Transepidermal water loss $\left(\mathrm{g} / \mathrm{m}^{2} \cdot \mathrm{hr}\right)$

\begin{tabular}{ccccccc} 
& \multicolumn{3}{c}{ Kefen $^{\circledR}$ plaster } & \multicolumn{3}{c}{ Surgical plster } \\
\cline { 2 - 7 } & Pre & $1 \mathrm{hr}$ & $6 \mathrm{hrs}$ & Pre & $1 \mathrm{hr}$ & 6hrs \\
\hline Mean & 7.07 & 5.53 & 4.73 & 6.40 & 4.87 & 4.27 \\
SD & 8.71 & 3.60 & 3.26 & 6.86 & 2.61 & 2.52 \\
\hline
\end{tabular}

Laser doppler flowmetry (volts)

\begin{tabular}{ccccccc} 
& \multicolumn{3}{c}{ kefen $^{\circledR}$ plaster } & \multicolumn{3}{c}{ Surgical plaster } \\
\cline { 2 - 7 } & Pre & 1hr & 6 hrs & Pre & 1hr & 6hrs \\
\hline Mean & 4.20 & 6.53 & 6.20 & 5.20 & 6.93 & 6.67 \\
SD & 1.86 & 2.26 & 2.88 & 1.78 & 2.15 & 2.72 \\
\hline
\end{tabular}




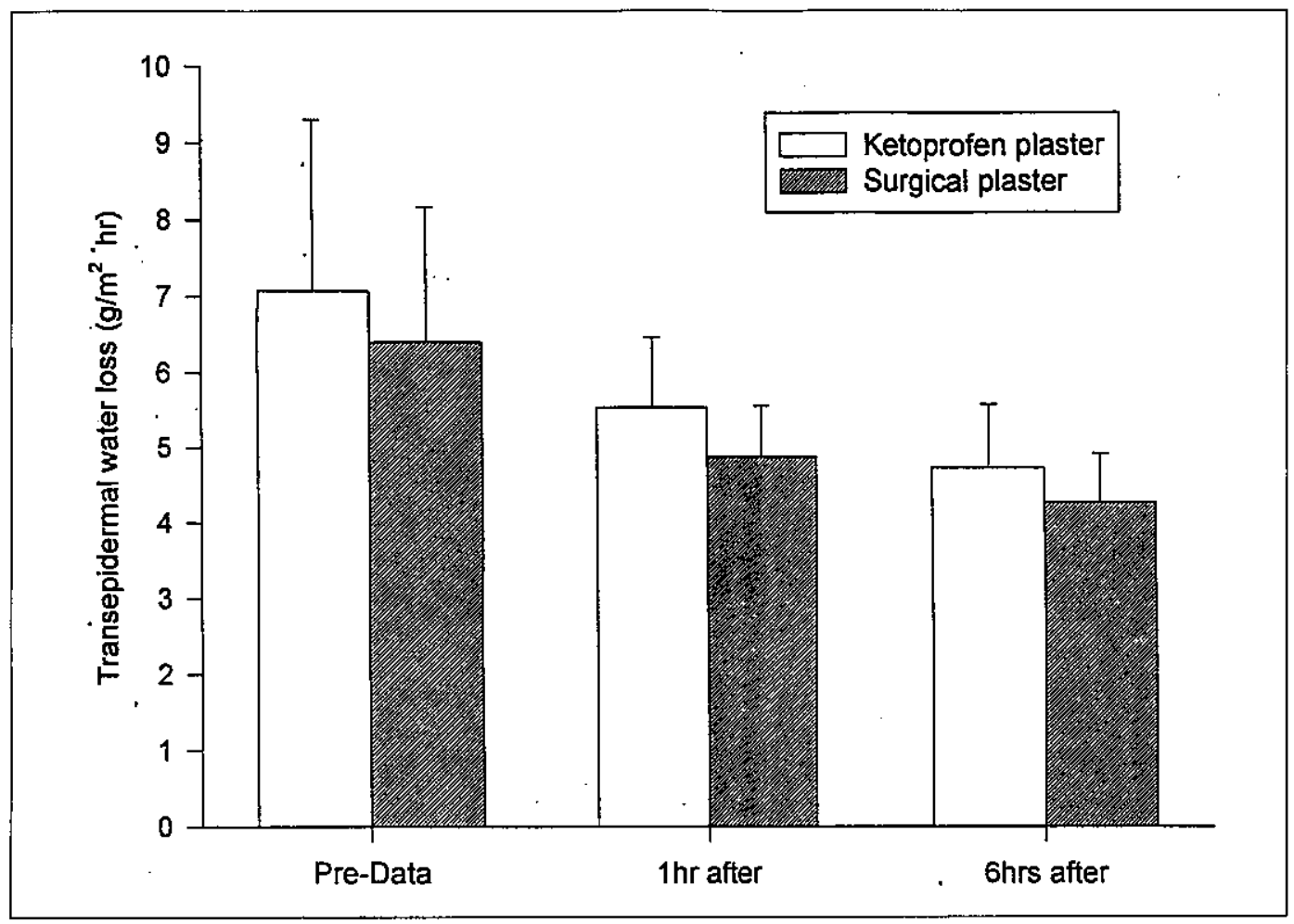

Fig. 3. Average transepidermal water loss in 15 subjects before application, 1 and 6 hours after 24 hour application period (mean \pm S.E.).

Vdarea인 요인과, 잔류량 검사로 산출한 흡수용 량보다 실제 전신순환으로 홉수된 약물의 양이 적음을 시사하며 이는 plaster 제거시 피부 부착 약물의 완벽한 회수가 불가능하여 실제보다 많 은 양이 홉수된 것처럼 산출되었을 가능성이 그 원인이 될 수 있을 것이다.

Ketoprofen $50 \mathrm{mg}$ 일일 4회 경구 투여시 진 통효과와 항염증효과를 보이는 혈장농도는 0.4 $6 \mu \mathrm{g} / \mathrm{ml}$ 으로 보고되었으며 진통효과의 $\mathrm{EC50}$ 는 $0.3 \mu \mathrm{g} / \mathrm{ml}$ 이나 실제 관절염 치료시 혈장농도와 치료효과의 관계는 명확하치 않은 것으로 보고 되고 있으며 특히 관절염 환자의 활액조직내 농 도는 매우 낮으며 치료효과와 상관이 낮다잉. 일 반적으로는 $50 \mathrm{mg}$ 이상 경구 반복투여시 활액
내 최고농도가 $0.9 \mu \mathrm{g} / \mathrm{ml}$ 정도로 보고되고 있 당. 본 plaster의 총혈장농도곡선하 면적과 평 균 약동학파라메터로 예측한 매 12시간 1 매 부 착시 얻어지는 항정상태 평균혈장농도는 Css. $\mathrm{avr}=$ AUCint,ss $/ \tau=171 \mathrm{ng} / \mathrm{ml}$ 로 $50 \mathrm{mg}$ 경 구투여시 유효 혈중농도의 약 $1 / 2-1 / 40$ 의 값 을 보인다(Figure 5). 그러나 이러한 차이는 기 존의 ketoprofen 경피흡수제제예서도 관찰되는 것으로 plaster가 국소조직의 염증이나 통중의 치료에 이용되어 전신 순환 도달전에 비교적 높 은 농도로 부착부위 주변 국소조직에 존재하므 로 ketoprofen의 경우에도 경피로 국소적으로 적-용시 부근 조직 및 활액으로 이행되는 농도는 횔씬 높을 것으로 유추된달. 임상적 유용성이 


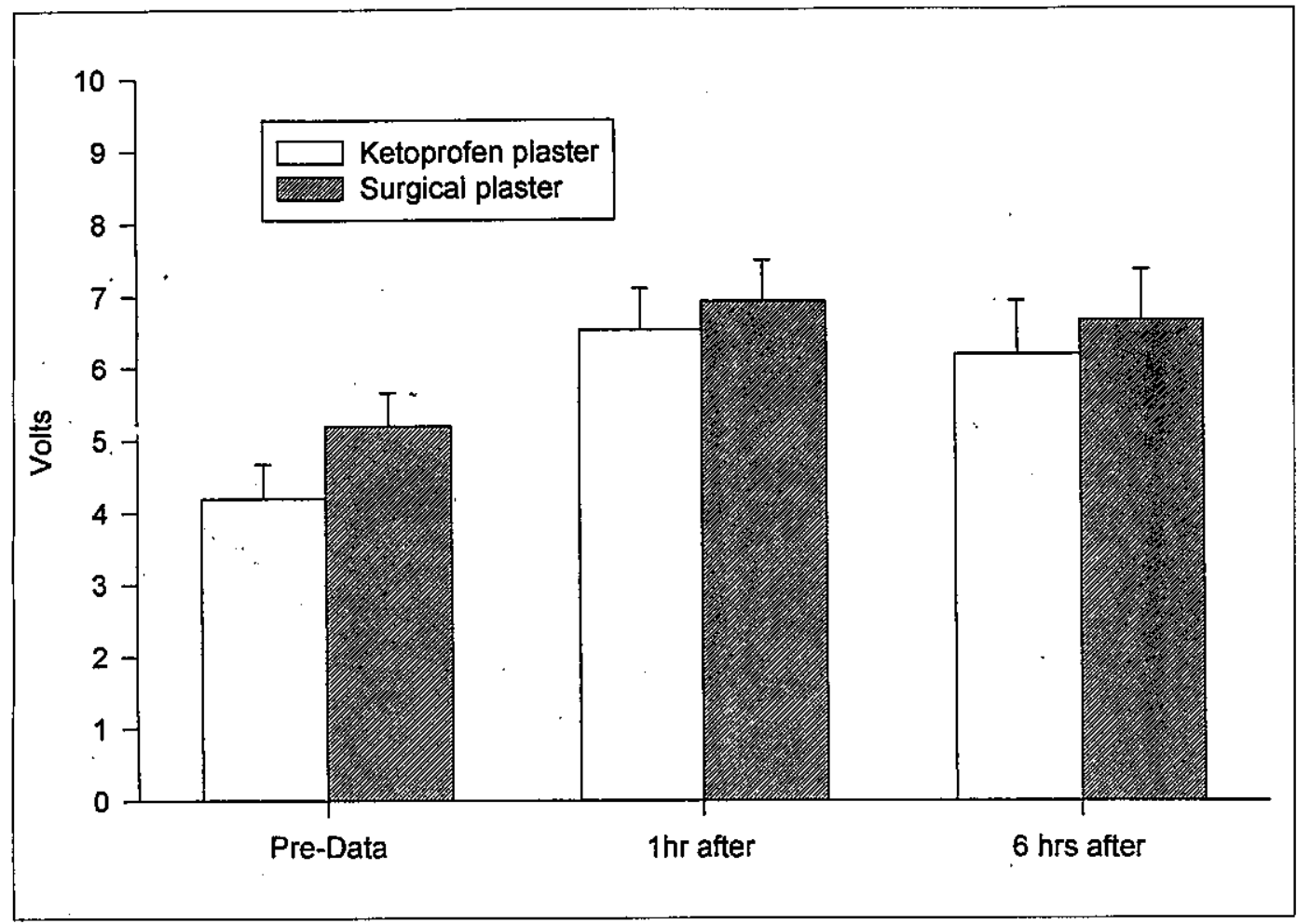

Fig. 4. Average changes in superficial blood flow measured by laser dopler flowmeter in 15 subjects before application, 1 and 6 hours after 24 hour application period (mean \pm S.E.).

$60 \%$ 인 일본의 Mohrus ${ }^{\circledR}$ 첩포제(ketoprofen)의 경우 24시간 반복 부착시 평균 혈장농도가 11.7 $\mathrm{ng} / \mathrm{ml}$ 인 것을 감안하고 ${ }^{2-4)}$ 본 ketoprofen plaster 제제를 24시간 간격으로 반복 부착시 Moh$\mathrm{rus}^{\circledR}$ 보다 약 10 배 이상의 농도인 $133 \mathrm{ng} / \mathrm{ml}$ 의 평균 형장농도를 보일 것으로 예측된다는 점을 고려할 때 $\mathrm{Kefen}^{\mathrm{B}}$ plaster는 그 약동학적 특성 으로 인한 임상적 효용성이 기존의 ketoprofen plaster보다 높을 가능성을 시사한다. 그러나 ketoprofen transdermal delivery system의 임상 젹 유용성은 최종적으로 적응증 환자를 대상으 로 한 임상효과 검증시헙에서 향후 검증되어야 할 사항이며, 가능한 경우 실제 활액내 약물농
도 및 염증 mediator의 감소 등을 검토하는 연 구가 필요할 것이다.

Kefen $^{(3)}$ plaster는 그 자극성 정도가 surgical plaster와 비교 시에도 차이가 없었으며 경피수 분소실이나 표재성혈류변화도 같은 촉정기구를 이용하여 6명의 피혐자에서 생리식염수를 첩포 한 후 관찰한 측정치와 유사한 정도로 24시간 부착 시에도 거의 피부 자극을 보이지 않았더릴. 따라서 본 ketoprofen $30 \mathrm{mg}$ 함유 첩포제인 Kefen (B) plaster제는 1매 24시간 부착 시에도 임상적 으로 유효한 호과를 안전하게 유지할 수 있을 제형으로 사료되며 차후 임상시험을 통해 이를 증명해야 할 것이다. 
- D. S. Yim, et al : Pharmacokinetics of Ketoprofen Plaster -

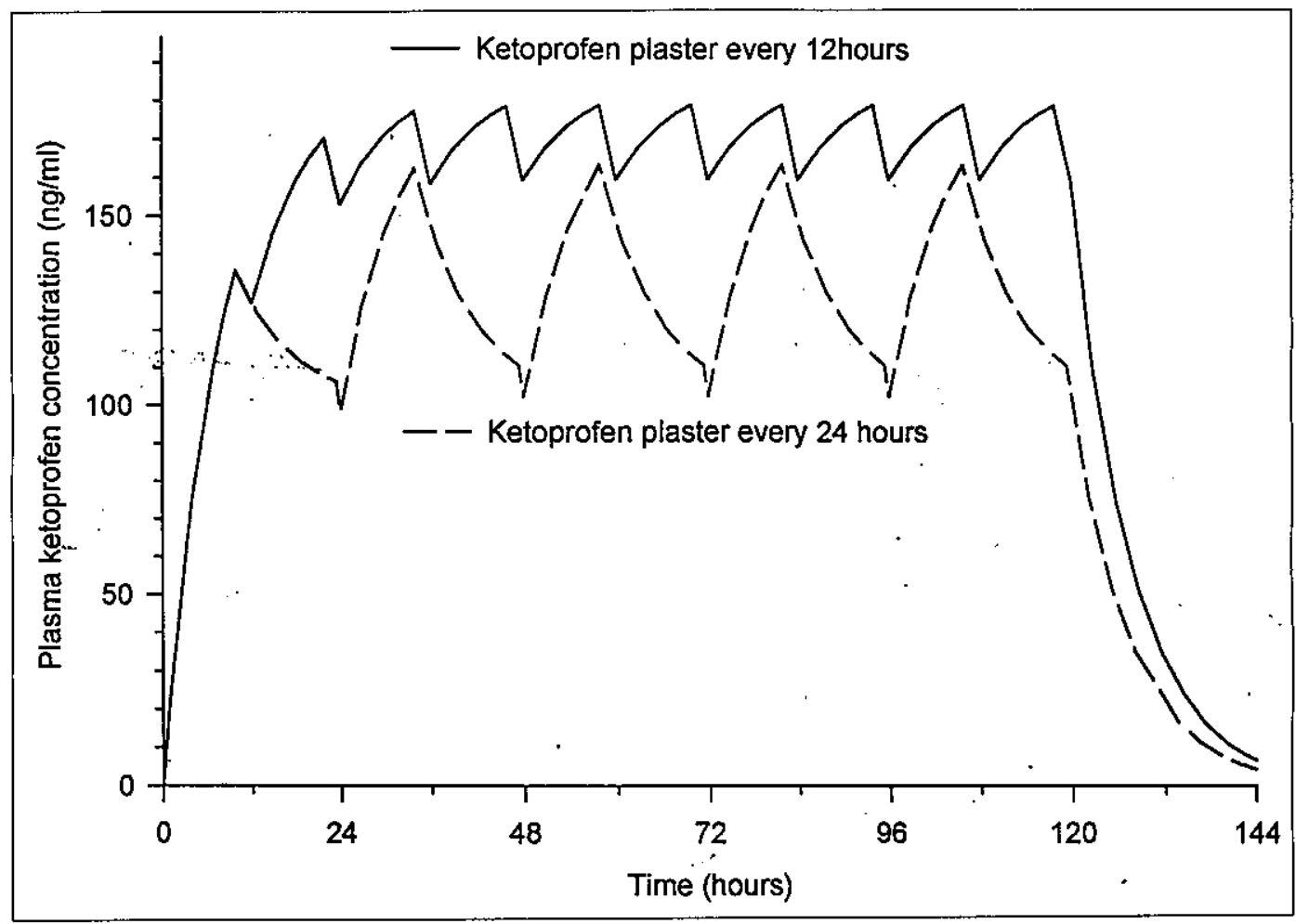

Fig. 5. Simulated plasma ketoprofen concentration after repeated application of a kefen ${ }^{(B)}$. plaster every 12 (line) or 24(broken line) hours. Average pharmacokinetic para meters of 1-compartment, 2-infusion model were used.

\section{요 약}

\section{연구배경 :}

비스테로이드계 소염진통제인 ke- toprofen은 짧은 반감기로 인한 잦은 경구투여 회수와 소화 기 부작용 등이 문제가 되어 투여회수와 전신부 작용을 줄일 수 있는 경피홉수첩포제의 개발이 유리한 약물이다. 본 연구에서는 국내 개발 ketoprofen 경피용 첩포제인 $\mathrm{Kefen}^{\mathrm{B}}$ plaster의 약동학적 특성과 피부자극성을 검토하고자 하였 다.

\section{방 법 :}

15 명의 신, 심 및 간기능이 정상인 건강인 피 험자를 대상으로 plaster 부착 전과 24시간 부착 기간동안 10 회의 채혈과 제거 후 6시간 동안 5 회의 채혈을 시행하였다. 혈장 ketoprofen 농도 는 고성능 액체크로마토그래피법을 이용하여 측 정하였고 plaster내 잔류량 측정으로 홉수량을 구하였고 약동학 특성은 compartment와 noncompartment model로 분석하였다. 피부자극성 은 plaster 부착전과 24시간 부착후 1시간과 6시 간 후에 transepidermal water loss와 laser doppler flowmeter를 이용한 표재성혈류의 변화를 
촉정하여 검토하였다.

\section{결 과 :}

Ketoprfen의 홉수량은 $11.21 \pm 3.09 \mathrm{mg}$ (평균士 표준편차)였고 이는 $30 \mathrm{mg}$ 용량 plaster의 $37.4 \%$ 에 해당하였다. 혈장 ketoprofen은 부착 후 6 내 지 14 시간에 최고농도인 $164.6 \mathrm{ng} / \mathrm{ml}$ 에 도달하 였다. 분포용적은 $0.44 \pm 0.26 \mathrm{~L} / \mathrm{kg}$, 반감기는 $2.44 \pm 0.48$ 시간이었으며 평균 청소율은 $0.06 \pm$ $0.02 \mathrm{~L} / \mathrm{hr} / \mathrm{kg}$ 이었다. 초기의 9.9 시간 동안 3.95 $\pm 1.84 \mathrm{mg}$ 가 빠른 훕수속도로 홉수되었고 총농 도곡선하면적은 $3.17 \pm 1.55 \mu \mathrm{g} / \mathrm{ml} \cdot \mathrm{hr}$ 이었다. 이들 약동학 파라메터로 예측된 매 12시간 간격 으로 부착시의 평균 혈장농도는 $171 \mathrm{ng} / \mathrm{ml}$ 이었 다. Kefen ${ }^{\mathbb{B}}$ plaster는 24시간 부착시 피부의 유 의한 자극을 보이지는 않았다.

\section{결 론 :}

이상의 결과로부터 ketoprofen 경퐈홉수제인 $\operatorname{Kefen}^{\circledR}$ 은 부착 후 24시간까지 지속적으로 홉수 를 보이며 상당한 농도에 도달하는 제제로 24시 간 동안 파부 부착시에도 유의한 피부자극을 보 이지 않았다. 비록 최종적으로 적응증 환자에서 그 유효성이 확인되어야 할 것이나 $\mathrm{Kefen}^{\circledR}$ 의 약동학 특성으로 볼 때 $\mathrm{Kefen}^{(\mathbb{B}}$ 은 매 12 내지 24시간 부착시 임상적 치료효과를 보일 것으로 기대되었다.

\section{Reference}

1) Flouvat B, Roux $A$ and Daslhotal-Landes $B$. Pharmacokinetics of ketoprofen in man after epeated percutanous administration. Arzneimittel forschung $1989 ; 39(7) ; 812-5$.

2) 管原幸子，大野博子，上田觶子. 케토프로펜 첨 부제(HKP-210)의 경피적용에 따른 환자 관절
액 및 조직내 농도의 검토. Therapeutic Res. $1987 ; 6: 295-300$.

3）管原幸子，大野博子，上田禮子. Hkp-210 경피 적용에 의한 환자의 관절액 및 조직내의 농 도의 검토 약리와 치료. $1986 ; 14: 591-597$.

4) 임동석, 장인진, 신상구, 유재학, 은희철. $\mathrm{Ke}-$ toprofen 첩포제(Ketotop ${ }^{B}$ )의 경피 적용에 따 른 혈장농도 및 피부자극의 검토. 임상약리 학회지 $1994 ; 2(1): 41-47$.

5) Draize JH. "Dermal toxicity" in appraisal of the safety of chemicals in drugs and cosmetics. Assoc. of food and Drug Officials of the U.S. Austin TX. 1959, pp 46-59

6) Royer RJ, Lapicque F, Netter P, Monot C, Bannwarth B, Cuve MC; Estimation by highperformance liquid chromatography of ketoprofen in plasma: application to the study of its protein binding. Biomed Pharm- acother 1986; 40: 100-5

7) Yim DS, Jang IJ, Shing SG, Eun HC. Pharmacokinetic analysis of transdermal drug delivery: Application to Ketoprofen patches. J Kor Soc Clin Pharmacol Ther $1994 ; 2$ : 146-149

8) Jamali F, Brocks DR. Clinical pharmacokinetics of ketoprofen and its enantiomers. Clin Pharmacokinet $1990 ; 19: 197-217$.

9) Netter P, Bannwaith B, Lapicque F, Harrewyn JM et al: Total and free ketoprofen in serum and synovial fluid after intramuscular injection. Clin Pharmacol Ther. 1987, 42 : $555-61$.

10) 유재학, 은희철, 서대현, 유일재. 비침습적 측정방법을 이용한 수종용제가 자극피부염 에 미치는 영향. 대한 피부과학회지 1994; 32(6) : 1026-1032. 